University of Louisville

ThinkIR: The University of Louisville's Institutional Repository

8-2014

\title{
An analysis of the potential effects of urbanization on the water quality of the middle fork of Beargrass Creek, Louisville, Kentucky.
}

Olivia Brooks

University of Louisville

Follow this and additional works at: https://ir.library.louisville.edu/etd

Part of the Geography Commons

\section{Recommended Citation}

Brooks, Olivia, "An analysis of the potential effects of urbanization on the water quality of the middle fork of Beargrass Creek, Louisville, Kentucky." (2014). Electronic Theses and Dissertations. Paper 158.

https://doi.org/10.18297/etd/158

This Master's Thesis is brought to you for free and open access by ThinkIR: The University of Louisville's Institutional Repository. It has been accepted for inclusion in Electronic Theses and Dissertations by an authorized administrator of ThinkIR: The University of Louisville's Institutional Repository. This title appears here courtesy of the author, who has retained all other copyrights. For more information, please contact thinkir@louisville.edu. 


\title{
AN ANALYSIS OF THE POTENTIAL EFFECTS OF URBANIZATION ON THE WATER QUALITY OF THE MIDDLE FORK OF BEARGRASS CREEK, LOUISVILLE, KENTUCKY
}

\author{
By \\ Olivia Brooks \\ B.A., Northern Kentucky University, 2012 \\ A Thesis \\ Submitted to the Faculty of the \\ College of Arts and Sciences of the University of Louisville \\ in Partial Fulfillment of the Requirements \\ for the Degree of
}

Master of Science

Department of Geography and Geosciences

University of Louisville

Louisville, Kentucky

August 2014 
Copyright 2014 by Olivia Brooks

All rights reserved 

AN ANALYSIS OF THE POTENTIAL EFFECTS OF URBANIZATION ON THE WATER QUALITY OF THE MIDDLE FORK OF BEARGRASS CREEK, LOUISVILLE, KENTUCKY

\author{
By \\ Olivia Brooks \\ B.A., Northern Kentucky University, 2012 \\ A Thesis Approved on
}

July 18,2014

by the following Thesis Committee:

C. Andrew Day

David Howarth

Andrew J. Battjes 


\section{ACKNOWLEDGEMENTS}

I would like to thank the University of Louisville"s Department of Geography and Geosciences for making this thesis proposal possible, in particular Dr. Carol Hanchette for the assistance and guidance throughout my time in the program. I would especially like to thank my major professor Dr. Andrew Day for his guidance, inspiration and patience. I would also like to express my thanks Dr. Jafar Hadizadeh for inspiring me and pushing me towards becoming a better researcher. I would also like to thank the other committee members, Dr. David Howarth and Andrew Battjes for their input and guidance. I would especially like to thank the University of Louisvillees Stream Institute for providing me the equipment used for water quality sampling. Finally, I would like to thank my family and friends. Without them I would not have been able to make this thesis possible. 


\begin{abstract}
AN ANALYSIS OF THE POTENTIAL EFFECTS OF URBANIZATION ON THE WATER QUALITY OF THE MIDDLE FORK OF BEARGRASS CREEK, LOUISVILLE, KENTUCKY

Olivia Brooks
\end{abstract}

July 18,2014

This thesis examined whether water quality diminished as a result of increasing pollution downstream along the Middle Fork of Beargrass Creek, Louisville, Kentucky in response to urbanization. Samples of key water quality indicators/pollutants were collected for 12 weeks (November - January) along the Middle Fork of Beargrass Creek at three different stream gauges. A spatial and statistical analysis was performed to verify any significant correlations between the water quality indicators and pollutants, and whether basin wide landcover/sewer outlet numbers led to an increase in these indicators downstream. Following ANOVA and Kruskal-Wallis statistical testing it was established that turbidity significantly increased downstream, while $\mathrm{pH}$ increased upstream in response to the changes in landcover along the Middle Fork. Further analysis is still needed to investigate the water quality of the stream across different seasons 
TABLE OF CONTENTS

PAGE

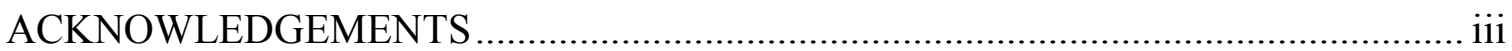

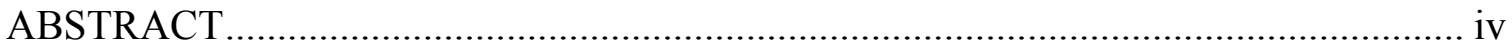

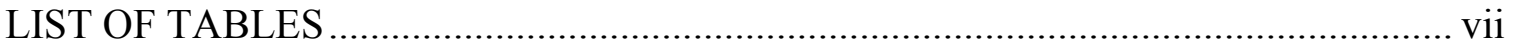

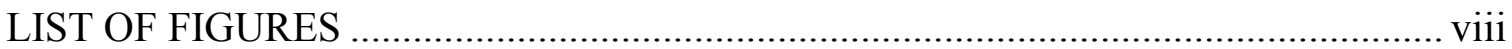

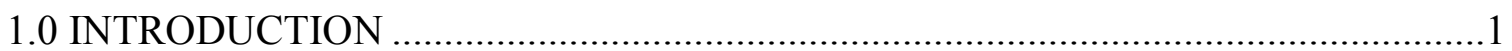

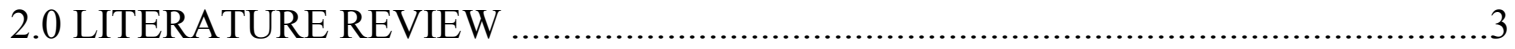

2.1 Water Quality and Pollution Monitoring in the US ......................................

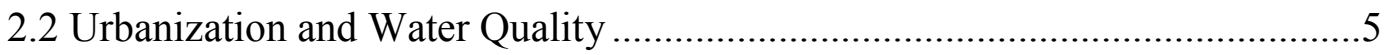

2.3 Monitoring Water Quality and Pollution in Beargrass Creek, Kentucky ..........7

2.4 Kentucky Water Quality Standards .........................................................

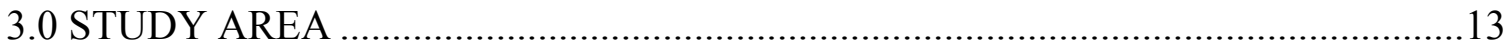

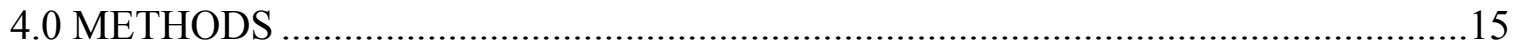

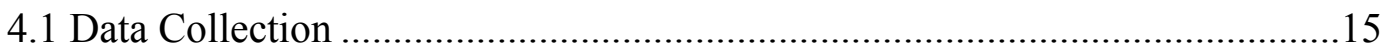

4.1.1 Water Quality/Pollution and Precipitation Data....................15

4.1.2 Landcover/Sewer Outlet Data .............................................17

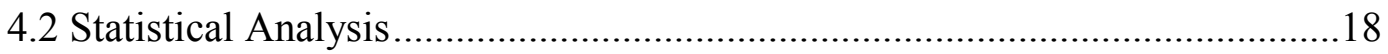

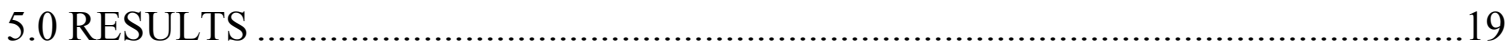

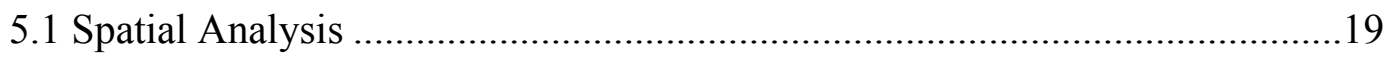

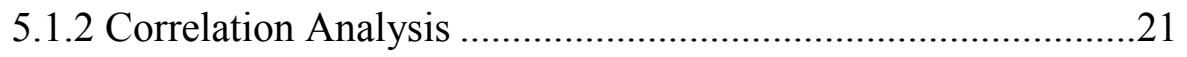

5.2 Variations in Water Quality Variables........................................................24

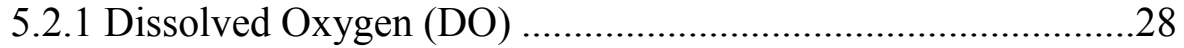

5.2.2 Specific Conductivity (SC) .............................................29

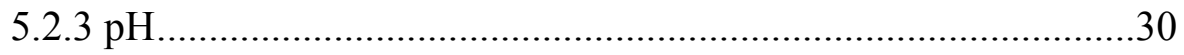


5.2.4 Temperature

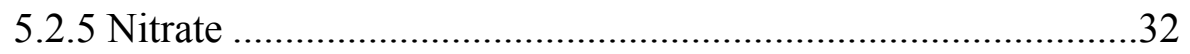

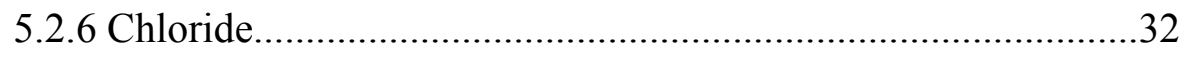

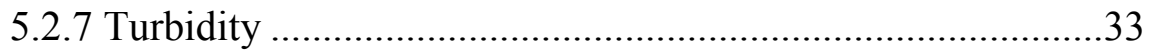

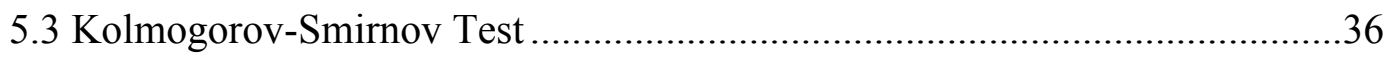

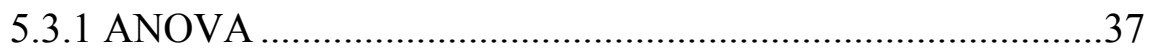

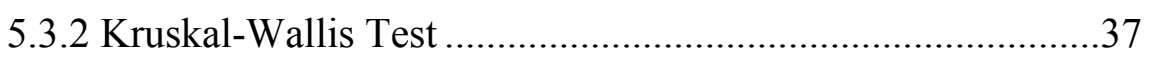

5.3.3 Mann-Whitney Test .................................................................

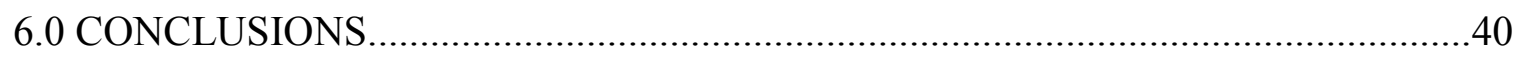

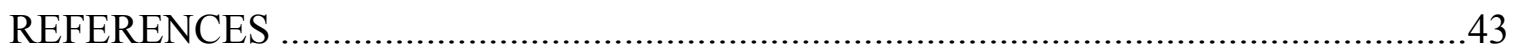

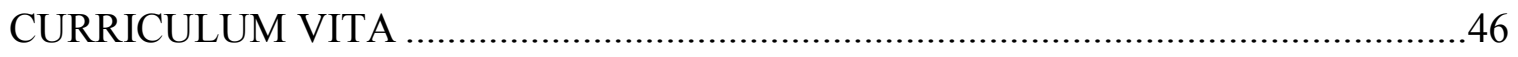




\section{LIST OF TABLES}

$\begin{array}{lll}\text { TABLE } & \text { PAGE }\end{array}$

1. The Kentucky Division of Water - Surface Water Standards ...................................10

2. The Kentucky Division of Water - Average Water Temperature ..............................11

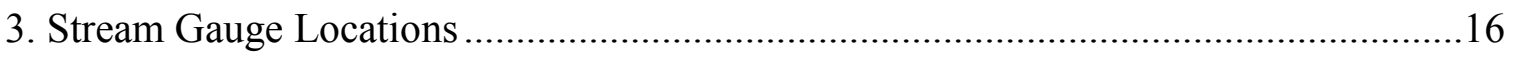

4. Total percentage of landcover upstream from each gauge site ................................20

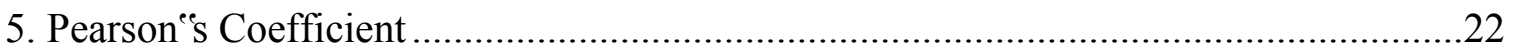

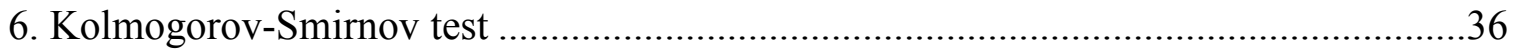

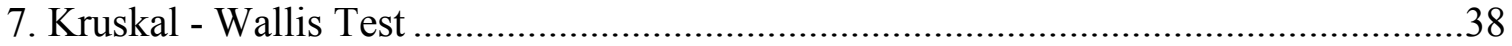

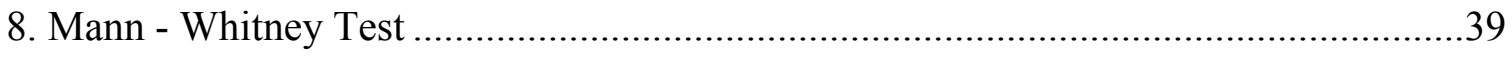




\section{LIST OF FIGURES}

$\begin{array}{lll}\text { FIGURE PAGE } & \text { PAR }\end{array}$

1. Map of Beargrass Creek indicating the USGS Stream Gauges .................................

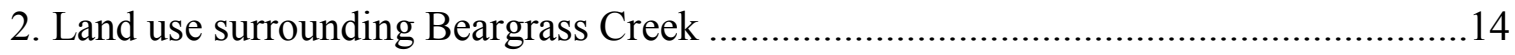

3. Map of Beargrass Creek indicating the areas of potential sewage outlets

along the creek and location of the USGS Stream Gauges................................17

4. Depicts dischrage levels between the three gauge sites ...........................................25

5. Illustrates the DO levels between the three gauge sites .......................................25

6. Demonstrates the SC levels between the three gauge sites.....................................26

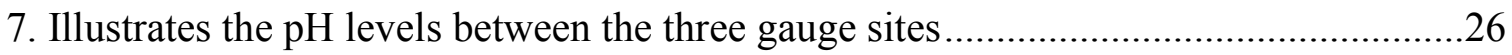

8. Depicts the temperature levels between the three gauge sites ...................................27

9. Illustrates the nitrate levels between the three gauge sites .......................................27

10. Demonstrates the chloride levels between the three gauge sites .............................28

11. Illustrates the turbidity levels between the three gauge sites ....................................28

12. Boxplots illustrating each water quality variable between the

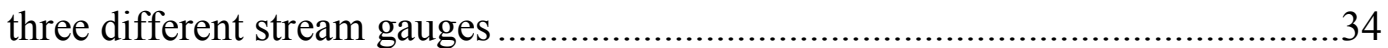




\subsection{INTRODUCTION}

Contrary to popular belief, surface water pollution in the U.S. did not begin with the onset of modern urbanization (Sartor, Boyd, and Agardy 1974; Brilly, Rusjan, and Vidmar 2006; Peters 2009; Haidary et al. 2013). In the early $18^{\text {th }}$ century forest clearing and farming practices in the U.S. caused major stream pollution following soil erosion from adjacent river valleys (Marsh 1965; Peters 2009). Although urbanization was not the true origin of stream pollution it has been an aggravating factor in stream degradation in ensuing years (Brilly, Rusjan, and Vidmar 2006; Peters 2009), as large-scale urbanization in the United States began to peak in the 1950"s (Peters 2009).

The terms water pollution and water quality are often used interchangeably. However, according to the United States Geological Survey (USGS) water quality describes three main features of water, these being chemical, physical, and biological (Perlman 2013). The chemical features of water are often attributed to agricultural and urban runoff. Physical attributes include water temperature, sight (turbidity), odor, and solids, which include the residues left behind from evaporation. Biological features of the water consist of carbon, hydrogen, oxygen, nitrogen, phosphorus and sulfur within plant and animal materials (Perlman 2013). Water pollution, on the other hand, involves any contamination of water from chemicals or other foreign substances that are detrimental to human, plant, or animal health, including industrial discharges, sewage and agricultural runoff (National Institute of Environmental Health Sciences 2014). As a result pollutants 
introduced to waterbodies will invariably lead to changes in the chemical, physical and biological features of the water quality.

This thesis research will ultimately seek to determine whether water quality diminishes as a result of increasing pollution downstream along the Middle Fork of Beargrass Creek, Kentucky, a typical heavily-urbanized watershed with a history of poor water quality. I hypothesize that stream segments will experience an increase in pollutants, and a subsequent decrease in water quality, downstream due to an increase in runoff from impervious surfaces and sewer outlets containing decaying vegetation, sewage wastewater and road salts. 


\subsection{LITERATURE REVIEW}

\subsection{Water Quality and Pollution Monitoring in the US}

The United States Geological Survey (USGS) monitors various basic water quality parameters through the National Water Information System (NWIS) web interface. This system monitors and records dissolved oxygen (DO), temperature, specific conductance (SC), $\mathrm{pH}$ and turbidity at over 25,000 stream gauges at 15 minute intervals across the US. DO represents the overall functionality and behavior of a stream ecosystem (Brilly, Rusjan, and Vidmar 2006; Bayram et al. 2013; Perlman 2013). Aquatic organisms in particular are heavily dependent on DO levels as any reduction in the DO will ultimately lead to a degradation of the aquatic systems.

Temperature plays a further key role for aquatic species by controlling DO levels. Higher temperatures result in lower DO levels. If the temperature of a stream or lake changes dramatically aquatic species diversity may decrease, especially for ectothermic species that have a narrow range of tolerance for temperature. Temperature may also affect the ability of some aquatic species to resist pollutant absorption (Perlman 2013).

SC measures the conduct of an electrical current carried by water. The conductance levels of streams are highly dependent on the amount of dissolved solids present in the water. As a result this variable helps to define the general water quality of a stream as a function of the total amount of dissolved solids present in stream water (Wenner, Ruhlman, and Eggert 2003). 
$\mathrm{pH}$ measures how acidic/basic the stream water is as a function of the relative amount of free hydrogen and hydroxyl ions in the water. Water that has more free hydrogen ions is acidic, whereas water that has more free hydroxyl ions is basic. The values may range from $0-14$, with $\mathrm{pH}$ values of less than 7 indicating acidic conditions, whereas a $\mathrm{pH}$ of greater than 7 indicates basic conditions. $\mathrm{pH}$ is a significant water quality indicator as it determines the solubility of chemical components such as phosphorous, carbon and copper amongst others (Peters 2009; Brilly, Rusjan, and Vidmar 2006; Bayram et al. 2013; Haidary et al. 2013; Perlman 2013).

Turbidity measures the amount of matter that is suspended in the stream water. Aquatic habitat areas and life can be harmed if turbidity in a stream is too high. For example, high turbidity levels can block out sunlight penetrating to the stream bed and choke aquatic habitats, whilst also promoting the re-growth of various pathogens, which in turn can lead to various health risks (Brilly, Rusjan, and Vidmar 2006; Bayram et al. 2013; Haidary et al. 2013; Perlman 2013). Consequently DO, temperature, SC, pH and turbidity play a significant role in determining the overall water quality of a stream for aquatic species diversity and human usage.

Surface water pollutants of interest, particularly concerning urban water quality, include nitrate and chloride. Nitrate is commonly produced from chemical fertilizers and from sewage discharge. Chloride may be introduced to streams following road salt application in winter months. Testing for nitrate and chloride could be vital for the surrounding areas regarding human usage and aquatic species habitats. Aquatic life could be threatened due to excessive growth of algae and other aquatic plants in response to the elevated nitrate levels. The additional algal growth could produce dead biomass along the 
bottom of the stream further diminishing aquatic lives by reducing DO levels (United States Environmental Protection Agency 2012).

\subsection{Urbanization and Water Quality}

Urban stream water quality is affected by a variety of factors from anthropogenic activities that tend to modify the chemical and physical characteristics of such streams (Brilly, Rusjan, and Vidmar 2006; Bayram et al. 2013; Cordy 2013). Urbanization generally results in an increase in impervious cover and number of sewer outlets, which may then significantly impact the adjacent hydrogeological and biophysical environment (Peters and Meybeck 2000). These impacts have been shown to include basic water quality parameters, for example levels of dissolved oxygen (DO), temperature, specific conductance (SC) and pH (Edelmann et al. 2005; Helms, Schoonover, and Feminella 2009; Haidary et al. 2013; Tu 2013). DO in particular is susceptible to significant reductions in response to bacteria and organic matter delivery via sewer outlets creating a large biochemical oxygen demand as the organic matter is consumed by the bacteria (Barco, Papiri, and Stenstrom 2008). Furthermore, sources of surface water pollution in urban areas may originate from specific land cover types associated with urbanization such as parking lots, golf courses and highways (Sartor, Boyd, and Agardy 1974; Brilly, Rusjan, and Vidmar 2006). In particular, runoff from impervious surfaces such as paved roads, parking lots, driveways, sidewalks often lead to pollutants including oil, grease, and various chemicals applied to roadways being washed into urban waterways (Sartor, Boyd, and Agardy 1974).

As a result, various studies have been conducted in an attempt to improve the understanding of urbanization impacts on water quality (Brilly, Rusjan, and Vidmar 
2006; Bayram et al. 2013; Cordy 2013). Brilly, Rusjan, and Vidmar (2006), for example, examined the impacts of urbanization on stream water along the Glinscica stream watershed which runs through the city of Ljubljana, Slovenia. In this study stream water quality was monitored over a two-year period from selected sampling points, including downstream of two highly urbanized areas, beginning in the summer of 2003. The authors focused on dissolved oxygen (DO) and nitrate at each site with results indicating high amounts of nitrate in the stream due to the usage of fertilizers and overflow from sewer outlets within the watershed leading to reduced DO levels. Their data also provided information on the sources of nitrate pollution responsible as well as other human activities influencing the quality of the water (Brilly, Rusjan, and Vidmar 2006).

Another key study by Bayram et al. (2013) further illustrated the impacts of stream pollution using the Harsit stream within the city of Gumushane, Turkey as a case study. Samples were collected from three appointed stations from March 2009 until February 2010. Various water quality parameters were measured to determine the impact of wastewater discharging into the stream from sewer outlets. This included chemical oxygen demand, ammonium nitrogen $\left(\mathrm{NH}_{4}{ }^{+}-\mathrm{N}\right)$, nitrite nitrogen $\left(\mathrm{NO}_{2}{ }^{-}-\mathrm{N}\right)$, nitrate nitrogen $\left(\mathrm{NO}_{3}{ }^{-} \mathrm{-N}\right)$, total Kjeldahl nitrogen (TKN) and total nitrogen (TN), orthophosphate phosphorus $\left(\mathrm{PO}_{4}{ }^{3-}-\mathrm{P}\right)$, methylene blue active substances (MBAS), water temperature, $\mathrm{pH}$, dissolved oxygen, and electrical conductivity.

The Harsit stream was susceptible to more harmful impacts from the sewer discharge during the summer to autumn months due to a decrease in stream discharge. The pollution measurements in the stream showed higher levels of $\mathrm{NH}_{4}{ }^{+}-\mathrm{N}, \mathrm{NO}_{2}{ }^{-}-\mathrm{N}$, $\mathrm{TKN}, \mathrm{PO}_{4}{ }^{3-}-\mathrm{P}$, and MBAS during this period. These physiochemical water-quality 
variables helped to determine the overall contamination within the stream resulting from urban land cover as well as industrial and agricultural land cover processes (Bayram et al. 2013).

These and other existing studies of urban impacts on stream water quality have made use of a variety of secondary datasets relating to urban water pollution, including the aforementioned USGS NWIS. Primary data sets may also be prepared through field water sampling and testing for water quality variables including dissolved oxygen (DO), total phosphorous, nitrates, herbicide and pesticide residues, and pharmaceutical compounds (Jarrett, Downs, and Grace-Jarrett 1998; Wenner, Ruhlman, and Eggert 2003; Bayram et al. 2013; Haidary et al. 2013).

\subsection{Monitoring Water Quality and Pollution in Beargrass Creek, Kentucky}

Watersheds in the city of Louisville, KY, including the Middle Fork of Beargrass Creek, are monitored regarding water quality by the Metropolitan Sewer District (MSD) in a series of reports. In 2011 the MSD conducted its latest "State of the Streams" investigation which reported on the ,pprogress of the stream ${ }^{e e}$ between 1999 and 2008 (Gray, Fitzgerald, and Trumbo 2011). In this study the MSD monitored aquatic life and retrieved water quality data from three gauges within the city located at Browns Lane, Old Cannons Lane, and Lexington Road (Gray, Fitzgerald, and Trumbo 2011), (Figure $1)$. 


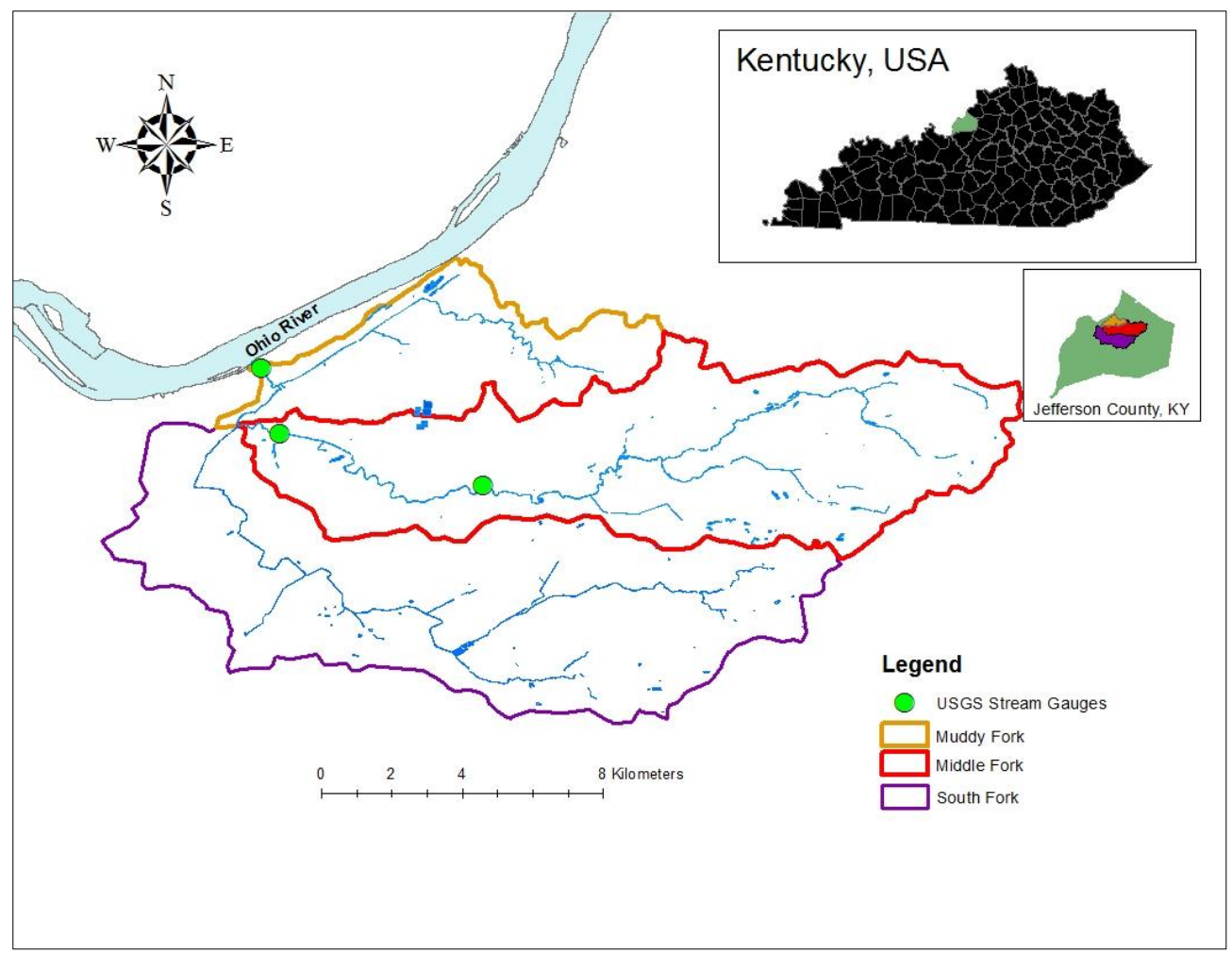

Figure 1

Map of Beargrass Creek indicating the USGS Stream Gauges.

The Middle Fork indicated a "poor" to "fair" improvement in aquatic habitats between 2002 and 2008 at Browns Lane. Old Cannons Lane also developed a "poor" to “fair" improvement in aquatic life between 1999 and 2008. Lexington Road portrayed “poor” habitat communities between 2005 and 2008. The USGS and MSD constantly monitor dissolved oxygen (DO) at each of these sites as part of their overall analysis. DO levels must be able to support aquatic life. The research by MSD in 2011 indicated there was a "poor" level of DO at Lexington Road downstream from the two sites between 2007 and 2008. This further indicated there had been a decrease in fish populations and aquatic habitats within the Middle Fork (Gray, Fitzgerald, and Trumbo 2011).

The overall results concluded that during the seven year interim period of the study, the Middle Fork had diminished from "good" to "fair" overall in its general health 
assessment (Gray, Fitzgerald, and Trumbo 2011). According to Gray, Fitzgerald, and Trumbo (2011) the Middle Fork is mainly surrounded by urban and suburban areas along with multiple sewer outlets. These factors could ultimately degrade the water quality of the Middle Fork and other streams within Louisville. There have been several other studies conducted on the Middle Fork of Beargrass Creek focusing on aquatic life and water quality (Jarrett, Downs, and Grace-Jarrett 1998; Ruhl and Jarrett 1999; Riseng, Wiley, and Stevenson 2004; MSD 2005; Tufail and Ormsbee 2009) ranging from the level of nutrients to the volume of urban run-off entering the watershed. Generally the water quality is classified as poor along the Middle Fork.

\subsection{Kentucky Water Quality Standards}

The Kentucky Division of Water (DOW) administrative regulations determine the surface water standards for the state of Kentucky. The administrative regulations establish provisions for the prevention and control of water pollution. Review and revision of these standards takes place in accordance with the Clean Water and Safe Drinking Water Acts. The surface water standards are required to maintain and protect human and animal health, habitat areas, and aquatic life (Kentucky Division of Water 2014). Section 4, Aquatic Life of the water quality standards, establishes the basic water quality standards for warm water aquatic communities including wild and domestic animals, arborous growth, agricultural, and industrial uses (Table 1). Table 2 illustrates the monthly average water temperature adapted from the DOW administrative regulations as water temperature is also impacted seasonally (Kentucky Division of Water 2014). If stream segments fail to meet these standards they may be classed as „impaired”. Impaired 
implies when waters are too polluted or meet outside the DOW standards (U.S. EPA 2013).

Table 1

The Kentucky Division of Water - Surface Water Standards

\begin{tabular}{lc}
\hline Variable & Minimum Standards \\
\hline $\mathrm{DO}(\mathrm{mg} / \mathrm{L})$ & $\geq 4.0$ \\
Temperature $\left({ }^{\circ} \mathrm{C}\right)$ & $\leq 31.7$ \\
$\mathrm{pH}(\mathrm{pH}$ unit $)$ & $6-9$ \\
Nitrate $(\mathrm{mg} / \mathrm{L}$ or $\mathrm{ppm})$ & $\leq 10$ \\
Chloride $(\mathrm{mg} / \mathrm{L})$ & $\leq 1200$
\end{tabular}


Table 2

The Kentucky Division of Water - Average Water Temperature

\begin{tabular}{|c|c|}
\hline Month/Date & Period Average \\
\hline & $\left({ }^{\circ} \mathrm{F}\right) \quad\left({ }^{\circ} \mathrm{C}\right)$ \\
\hline January 1-31 & $45 \quad 7$ \\
\hline February 1-29 & $45 \quad 7$ \\
\hline March 1-15 & 11 \\
\hline March 16-31 & 54 \\
\hline April 1-15 & 58 \\
\hline April 16-30 & 18 \\
\hline May 1-15 & 20 \\
\hline May 16-31 & 75 \\
\hline June 1-15 & 80 \\
\hline June 16-30 & 83 \\
\hline July 1-31 & 84 \\
\hline August 1-31 & 84 \\
\hline September 1-15 & 84 \\
\hline September 16-30 & 82 \\
\hline October 1-15 & 77 \\
\hline October 16-31 & 72 \\
\hline November 1-30 & 67 \\
\hline December 1-31 & 52 \\
\hline
\end{tabular}


The basic water quality variables mentioned in Table 1 are significant indicators that will help determine the potential impacts of urban areas on the Middle Fork of Beargrass Creek. Urban areas have been shown to degrade streams to the point they have become significantly polluted and aquatic life totally diminished. Historically pollution from urban areas has already caused much erosion and water quality degradation along the Middle Fork (Jarrett, Downs, and Grace-Jarrett 1998; MSD 1999; MSD 2005). Further testing of these water quality and pollution variables along the Middle Fork will help determine how urbanization has continued to impact the water quality of the stream. 


\subsection{STUDY AREA}

Beargrass Creek, located in the city of Louisville, KY is split into three main channels: the Muddy Fork, Middle Fork, and South Fork (Figure 2). The USGS and Metropolitan Sewer District of Louisville (MSD) have monitored the streams for pollution since 1988 due to the increase of urban development surrounding each creek. The Middle Fork watershed includes a mixture of undeveloped lands, parks, public lands, industrial, and residential land cover. Residential cover accounts for the highest percentage of land use with roughly $56 \%$ coverage (MSD 1999). Of the three watersheds, the Middle Fork expands further into Jefferson County flowing beneath and near highly urbanized areas. As a result, this thesis research is both timely and significant due to the Middle Fork flowing through these highly urbanized areas that could potentially affect the health of the stream. 


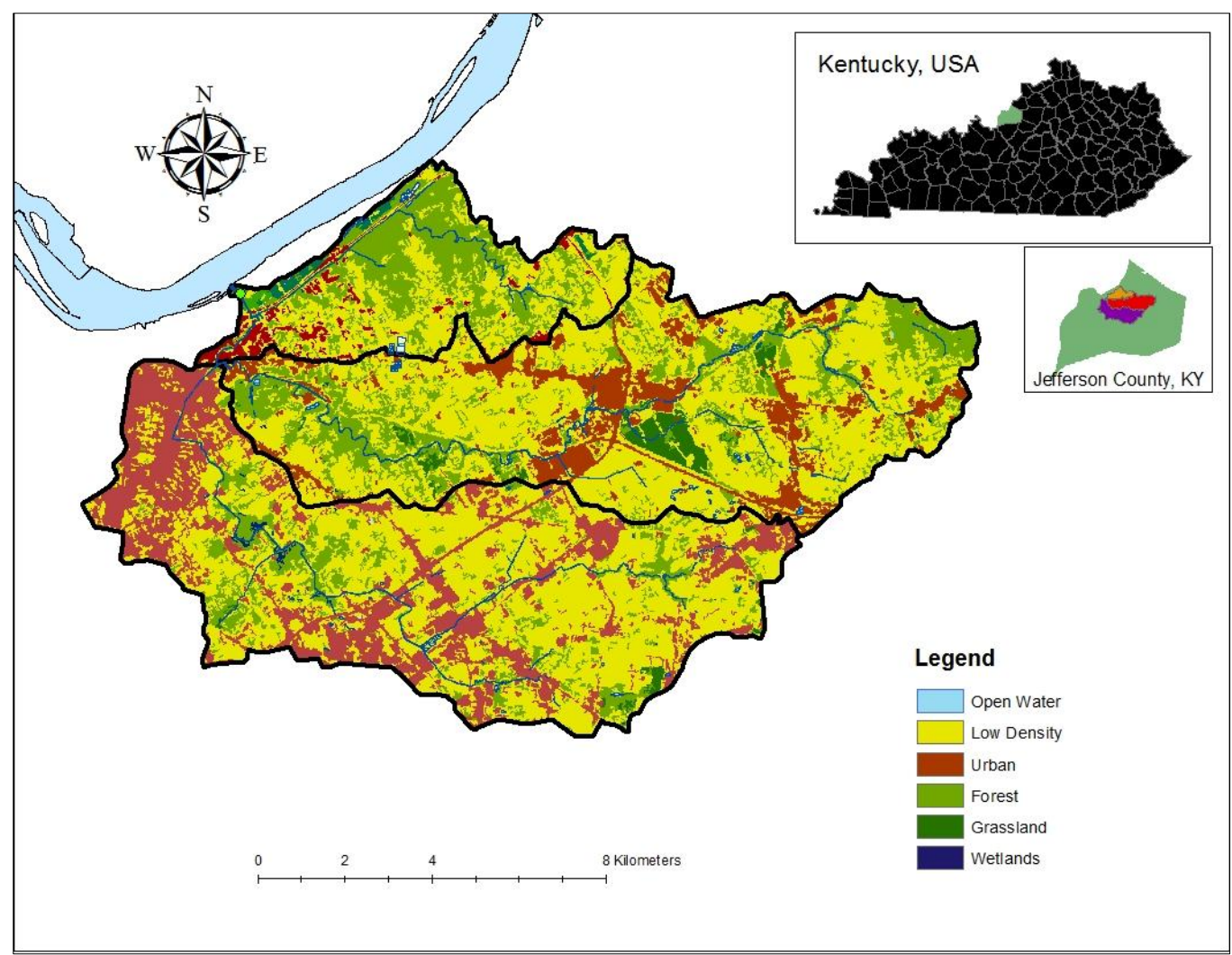

Figure 2

Land use surrounding Beargrass Creek. 


\subsection{METHODS}

\subsection{Data Collection}

\subsubsection{Water Quality/Pollution and Precipitation Data}

Water quality data were obtained from 3 USGS stream gauges stationed along the Middle Fork of Beargrass Creek located by Old Cannons Lane, Lexington Road, and River Road in Louisville, KY (Table 3; refer to Figure 1 for locations). The gauges supplied instantaneous values of dissolved oxygen (DO in $\mathrm{mg} / \mathrm{L})$, temperature $\left({ }^{\circ} \mathrm{C}\right)$, specific conductance ( $\mathrm{SC}$ in $\mu \mathrm{S} / \mathrm{cm}$ ), $\mathrm{pH}$ and discharge ( $\mathrm{Q}$ in cfs) from the NWIS (USGS 2013). Water pollution data, including nitrate ( $\mathrm{ppm})$, chloride (mg/L) and turbidity (ntunephelometric turbidity units which measure the degree of light scattered by suspended particles), which was not available at these gauges, were also collected through field samples taken at each of the stream gauge sites at times that corresponded to the USGS water quality dataset measurements. Samples were collected in a bucket approximately $0.5 \mathrm{~m}$ from the bank adjacent to each of the USGS gauge sites. Before each sampling event the bucket was rinsed through thoroughly three times with water taken directly from the stream in accordance with standard sampling protocol (Connors 2004). 


\section{Table 3}

$\underline{\text { Stream Gauge Locations }}$

\begin{tabular}{llll} 
Sample & $\begin{array}{l}\text { Cannons Lane at } \\
\text { Beargrass Creek }\end{array}$ & $\begin{array}{l}\text { Lexington Road at } \\
\text { Beargrass Creek }\end{array}$ & $\begin{array}{l}\text { River Road at } \\
\text { Beargrass Creek }\end{array}$ \\
\hline Latitude & $38^{\circ} 14^{\mathrm{e}} 14^{\prime \prime}$ & $38^{\circ} 15^{\circ} 01^{\prime \prime}$ & $38^{\circ} 16^{\circ} 01^{\prime \prime}$ \\
Longitude & $85^{\circ} 39^{\circ e} 53^{\prime \prime}$ & $85^{\circ} 43^{\circ} 00^{\prime \prime}$ & $85^{\circ} 43^{\mathrm{ec}} 17^{\prime \prime}$ \\
$\begin{array}{l}\text { Gauge \# } \\
\text { (USGS) }\end{array}$ & 3293000 & 393500 & \\
Watershed & Middle Fork & Middle Fork & 3293510 \\
From Gauge & & & $\begin{array}{l}\text { Muddy, Middle, } \\
\text { South Fork }\end{array}$
\end{tabular}

Water samples were tested for nitrate and turbidity at the sites themselves using a LaMotte Nitrate-Nitrogen Kit and Hach 2100Q Portable Turbidimeter with water drawn directly from the bucket. A further water sample was collected from the bucket into a smaller container that had been sterilized beforehand and stored on ice for transportation back to the University of Louisville Department of Geography and Geosciences for chloride testing using a LaMotte Chloride kit. The data were collected at specific times, from November 2013 to January 2014 once a week for a total period of 12 weeks. Precipitation data for each 48-hour period, prior to the data collection times, was also obtained from an MSD station upstream of the stream gauge sites in order to account for any increase in discharge along the stream during the study period which could potentially affect the water quality and pollution readings. 


\subsubsection{Landcover/Sewer Outlet Data}

Land cover data upstream from each gauge were obtained from a 30-meter resolution raster dataset, available from the National Landcover Dataset (NLCD), (Jin et al. 2013). Sewer overflow sites were obtained from the Louisville/Jefferson County Information Consortium (LOJIC 2013) in point shapefile format. Both datasets were loaded into ArcGIS in order to calculate the proportion of land cover and number of sewer outlets upstream from each gauge. A 200meter buffer was further applied along the Middle Fork to include the sewage outlets directly adjacent to the stream that could potentially impact water quality (Figure 3 ). These two datasets were used to conduct a spatial analysis of potential water quality and pollution along the Middle Fork.

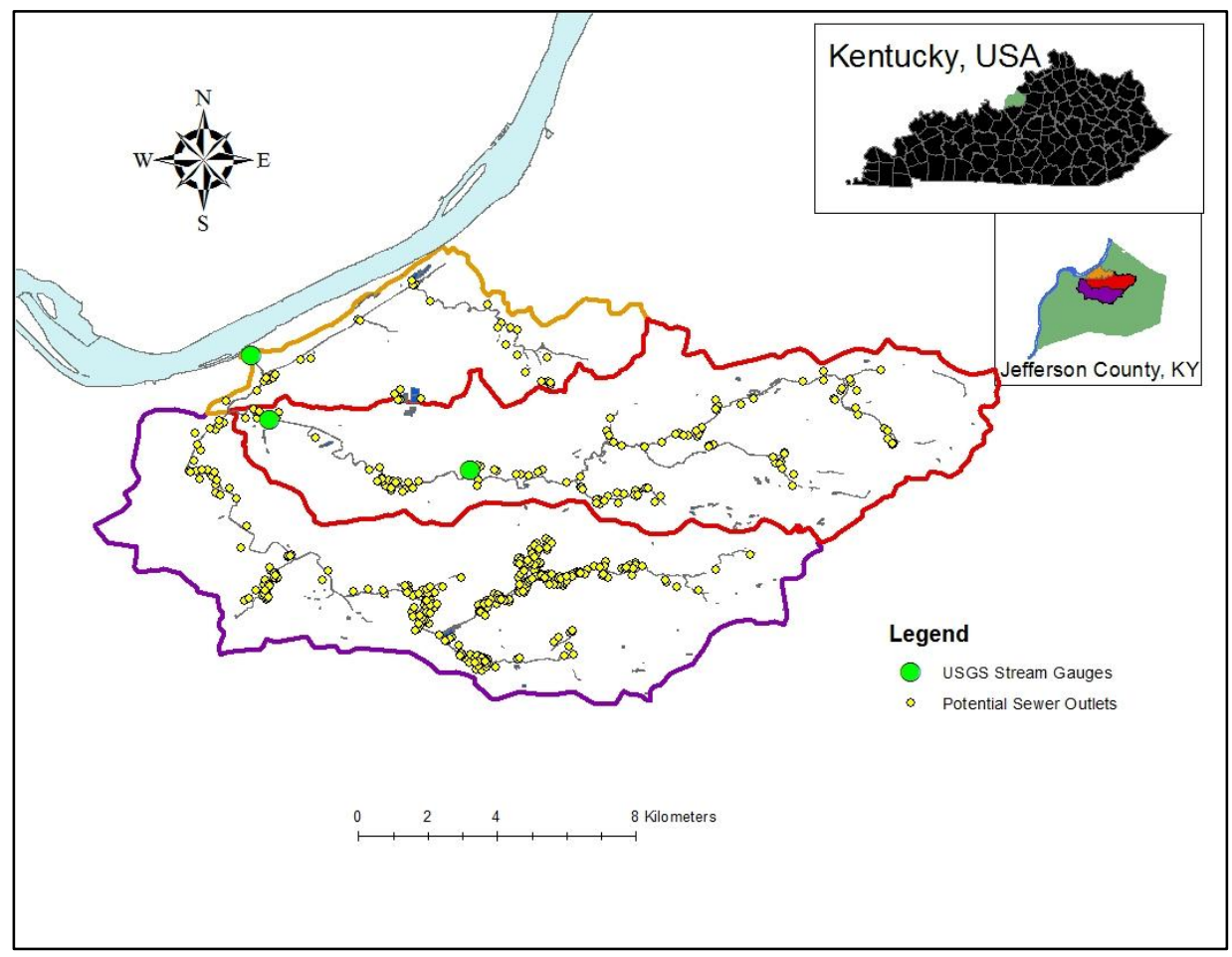

\section{Figure 3}

Map of Beargrass Creek indicating the areas of potential sewage outlets along the creek and location of the USGS Stream Gauges. 


\subsection{Statistical Analysis}

To test whether water quality diminished downstream of Beargrass Creek, boxplots for each variable at the three gauge sites were generated to analyze the descriptive statistics and variance of the water quality and pollution data over the entire data collection period. Measurements of DO, temperature, $\mathrm{pH}$, nitrate and chloride were also checked against the state standards (Table 1) to determine if any of the standards were violated at any time during the study period. A Pearson correlation analysis was then applied to check for correlation between each of the water quality/pollution variables, along with proportion of land cover and number of SSO's upstream from each gauge. Following this, the data were checked for normality using the KolmogorovSmirnov test. Data displaying a normal distribution were further analyzed using OneWay Analysis of Variance (ANOVA) to compare the mean values of each pollutant between the sampling sites. Kruskal-Wallis and Mann-Whitney tests were then applied if non-parametric procedures were required to compare the median values at each site. These procedures have been well documented in similar studies concerning urbanization impacts on water quality and pollution (Gerner and Waddell 2003; Gray 2004; Edelmann et al. 2005; Bayram et al. 2013; Haidary et al. 2013). 


\subsection{RESULTS}

\subsection{Spatial Analysis}

The percentage of landcover varied along each stream gauge (Table 4). The upstream gauge (Cannons Lane) had an 18\% urban coverage. This included medium to high-density urban areas such as industrial landcover and airports with 50-100\% impervious cover (NLCD 2013). Low density urban areas (20-49\% impervious cover), including golf courses, parks, subdivisions, etc., accounted for 59\% of landcover. Forested areas accounted for $18 \%$, open water $0.2 \%$, and grasslands including agricultural use accounted for $4 \%$ of landcover.

The midstream gauge (Lexington Road) had similar landcover percentages to Cannons Lane. The surrounding urban land use was 16\%, while low density urban areas accounted for $59 \%$ landcover. Forested areas were $22 \%$, open water $0.2 \%$ and grasslands $3 \%$ landcover.

The downstream gauge (River Road) collects discharge from all three streams within Beargreass Creek. The low density urban percentage of landcover accounted for $50 \%$, urban areas $20 \%$, forested areas $24 \%$, open water $0.4 \%$, wetlands $0.3 \%$ and grasslands $4 \%$.

There were also a high number of sewage outlets along each stream segment upstream of each gauge (Figure 3). Ninety sewage outlets were located upstream from 
Cannons Lane, within a 200m stream buffer. Upstream from Lexington Road there were 116 sewage outlets. River Road includes the total number of outlets from the South, Middle, and Muddy Fork combined giving 328 sewage outlets. However, there were no significant correlations between the water quality variables and the number of sewage outlets upstream of each gauge. The water quality variables also indicated no significant correlation with the proportions of landcover upstream of each gauge, especially the urban land covers. The lack of correlation is most likely a result of the decreasing urban and low density urban cover that occurs downstream of the Middle Fork, which was not expected. The addition of the Muddy Fork, in particular, draining to the River Road gauge actually increased the proportion of forested, grassland and wetland coverage over the upstream gauges. As a result the proportional area commonly attributed to pollutant sources reducing water quality diminishes downstream of the Middle Fork.

\section{Table 4}

Total percentage of landcover upstream from each gauge site

\begin{tabular}{llll} 
Landcover (\%) & $\begin{array}{l}\text { Cannons } \\
\text { Lane (\%) }\end{array}$ & $\begin{array}{l}\text { Lexington } \\
\text { Road (\%) }\end{array}$ & $\begin{array}{l}\text { River } \\
\text { Road (\%) }\end{array}$ \\
\hline \multirow{2}{*}{ Open Water } & 0.17 & 0.22 & 0.39 \\
Rural & 59.58 & 58.39 & 50.67 \\
Urban & 18.06 & 16.01 & 20.42 \\
Forest & 18.32 & 21.88 & 24.03 \\
Grasslands & 3.87 & 3.48 & 4.14 \\
Wetlands & - & 0.02 & 0.34 \\
& & & \\
\hline
\end{tabular}




\subsubsection{Correlation Analysis}

A correlation analysis was applied to determine possible relationships between the water quality variables based on a $95 \%$ confidence level, or a P-value of 0.05 . Table 5 displays the output for the correlation analysis of the water quality data at each site. Overall there were 33 out of 42 pairs of water quality variables that were significantly statistically correlated to one another. Further analyses of sample correlations are provided under the discussion of each water quality variable below. 


\section{Table 5}

$\underline{\text { Pearson's Coefficient }}$

Cannons Lane - Correlations

\begin{tabular}{|c|c|c|c|c|c|c|c|}
\hline & Turbidity & Nitrate & Chloride & Temperature & DO & PH & SC \\
\hline Turbidity & 1 & .455 & .473 & -.437 & .225 & .003 & .187 \\
Nitrate & .455 & 1 & $.655^{*}$ & -.572 & .499 & -.377 & .306 \\
Chloride & .473 & $.655^{*}$ & 1 & $-.928^{* *}$ & .568 & .028 & $.606^{*}$ \\
Temperature & -.437 & -.572 & $-.928^{* *}$ & 1 & $-.686^{*}$ & -.118 & $-.652^{*}$ \\
DO & .225 & .499 & .568 & $-.686^{*}$ & 1 & .101 & $.781^{* *}$ \\
pH & .003 & -.377 & .028 & -.118 & .101 & 1 & .116 \\
SC & .187 & .306 & $.606^{*}$ & $-.652^{*}$ & $.781^{* *}$ & .116 & 1 \\
\hline
\end{tabular}

*. Correlation is significant at the 0.05 level (2-tailed).

**. Correlation is significant at the 0.01 level (2-tailed).

Lexington Road - Correlations

\begin{tabular}{|c|c|c|c|c|c|c|c|}
\hline & Turbidity & Nitrate & Chloride & Temperature & DO & PH & SC \\
\hline Turbidity & 1 & .283 & -.046 & .030 & -.301 & -.144 & -.048 \\
Nitrate & .283 & 1 & .026 & -.561 & .286 & .481 & .231 \\
Chloride & -.046 & .026 & 1 & -.488 & .411 & .357 & $.948^{* *}$ \\
Temperature & .030 & -.561 & -.488 & 1 & $-.845^{* *}$ & $-.908^{* *}$ & $-.704^{*}$ \\
DO & -.301 & .286 & .411 & $-.845^{* *}$ & 1 & $.892^{* *}$ & $.584^{*}$ \\
pH & -.144 & .481 & .357 & $-.908^{* *}$ & $.892^{* *}$ & 1 & .559 \\
SC & -.048 & .231 & $.948^{* *}$ & $-.704^{*}$ & $.584^{*}$ & .559 & 1 \\
\hline
\end{tabular}

*. Correlation is significant at the 0.05 level (2-tailed).

**. Correlation is significant at the 0.01 level (2-tailed). 
River Road - Correlations

\begin{tabular}{|c|c|c|c|c|c|c|c|}
\hline & Turbidity & Nitrate & Chloride & Temperature & DO & PH & SC \\
\hline & & & & & & & \\
Turbidity & 1 & .379 & $.691^{*}$ & -.211 & .127 & .174 & .662 \\
Nitrate & .379 & 1 & .354 & -.499 & .543 & .474 & .422 \\
Chloride & $.691^{*}$ & .354 & 1 & -.527 & .457 & .209 & $.984^{* *}$ \\
Temperature & -.211 & -.499 & -.527 & 1 & $-.937^{* *}$ & $-.802^{* *}$ & -.618 \\
DO & .127 & .543 & .457 & $-.937^{* *}$ & 1 & $.783^{* *}$ & .529 \\
pH & .174 & .474 & .209 & $-.802^{* *}$ & $.783^{* *}$ & 1 & .312 \\
SC & .662 & .422 & $.984^{* *}$ & -.618 & .529 & .312 & 1 \\
\hline
\end{tabular}

*. Correlation is significant at the 0.05 level (2-tailed).

**. Correlation is significant at the 0.01 level (2-tailed). 


\subsection{Variations in Water Quality Variables}

Water quality variables, including $\mathrm{DO}, \mathrm{SC}, \mathrm{pH}$, temperature, turbidity, nitrate, and chloride showed some variation over time between each sampling site (Figures 4-11). Each stream gauge indicated an increase over time for DO, chloride, SC, turbidity, and discharge. DO likely increased due to the decrease in temperatures. Chloride, turbidity, and SC likely increased due to the addition of road salts and snow melt washing into the stream, along with other chemical constituents/solids as the winter season progressed. This particular winter was one of the coldest on record with air temperatures falling well below $0^{\circ} \mathrm{C}$ on many occasions, accompanied by multiple snowfall events. The water quality variable that indicated a decrease over time from all three-stream segments was temperature, while $\mathrm{pH}$ and nitrate were the only variables to show no obvious trend over time at each sampling site. It should be further noted that there was no significant amount of precipitation in any 48-hour period before each sample was collected. The largest value of precipitation before samples were collected was $0.25 \mathrm{~mm}$. 


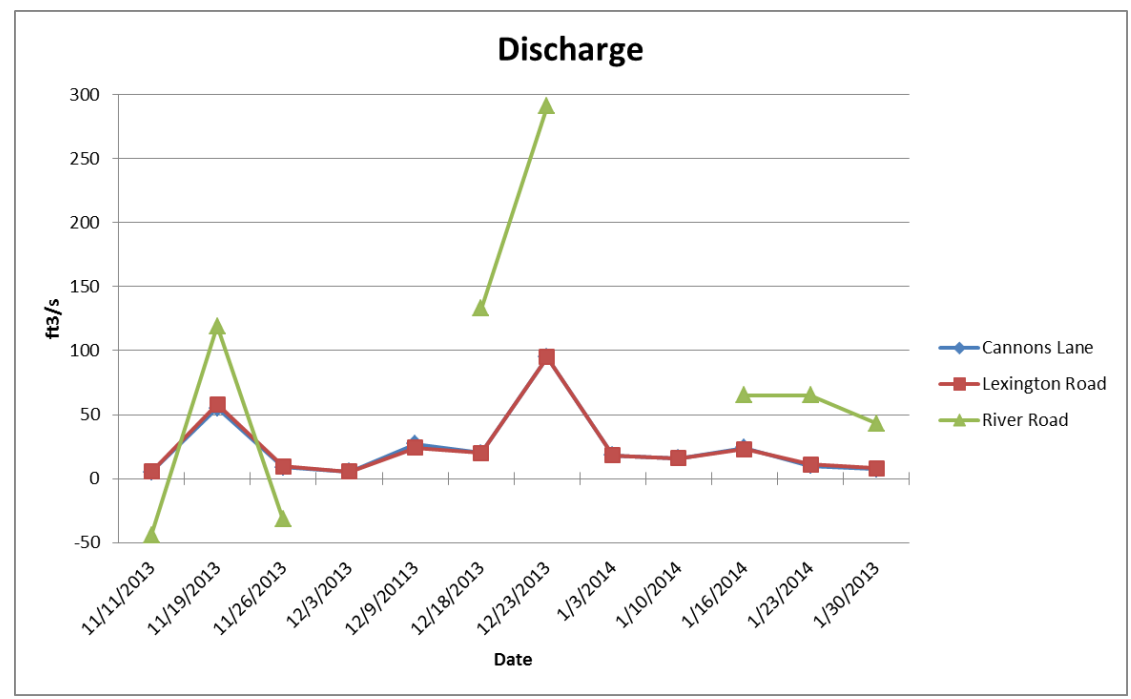

Figure 4 depicts dischrage levels between the three gauge sites of Middle Fork of Beargrass Creek.

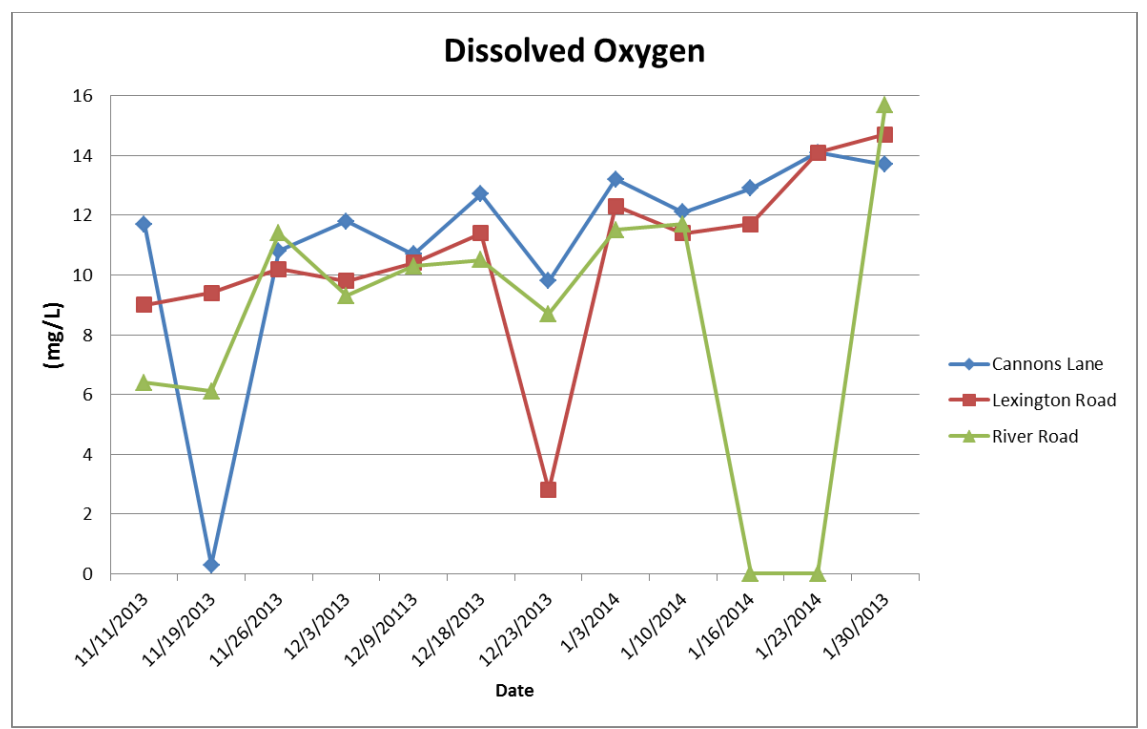

Figure 5 illustrates the DO levels between the three gauge sites. 


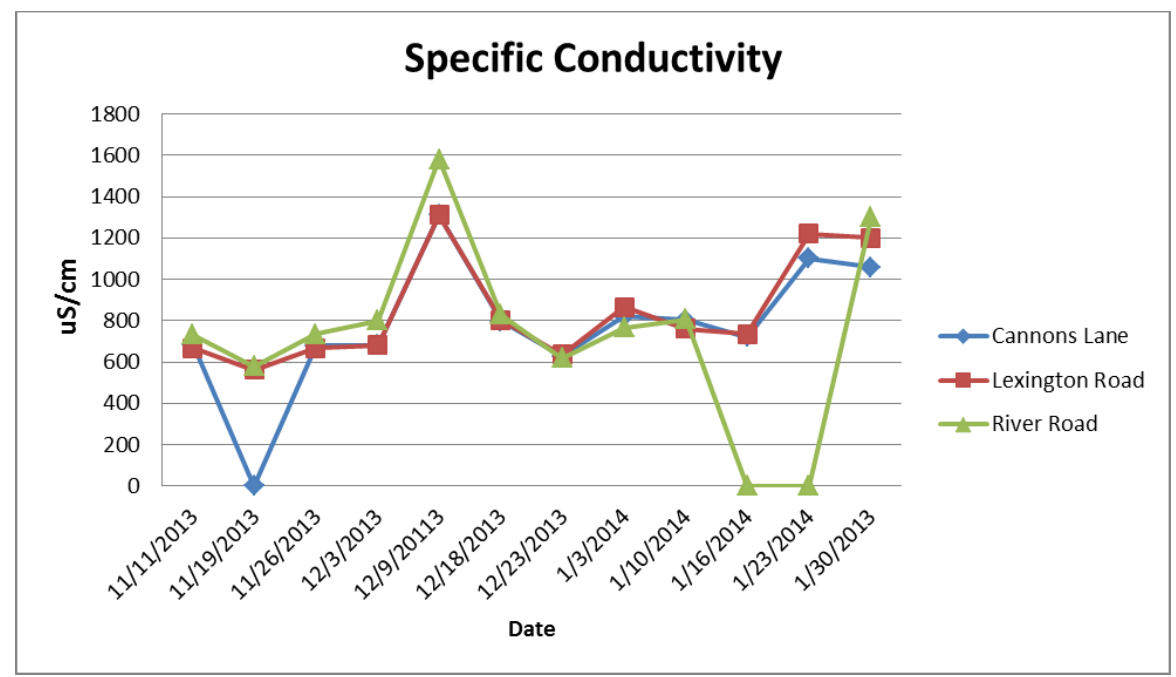

Figure 6 demonstrates the SC levels between the three gauge sites.

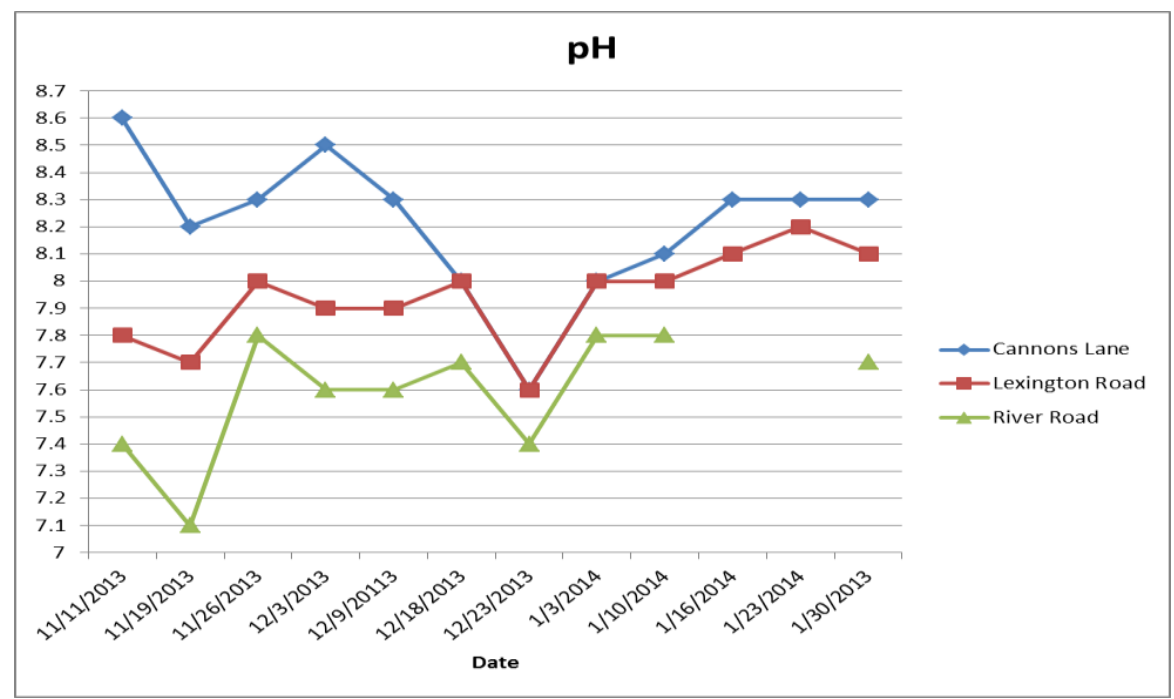

Figure 7 illustrates the $\mathrm{pH}$ levels between the three gauge sites. 


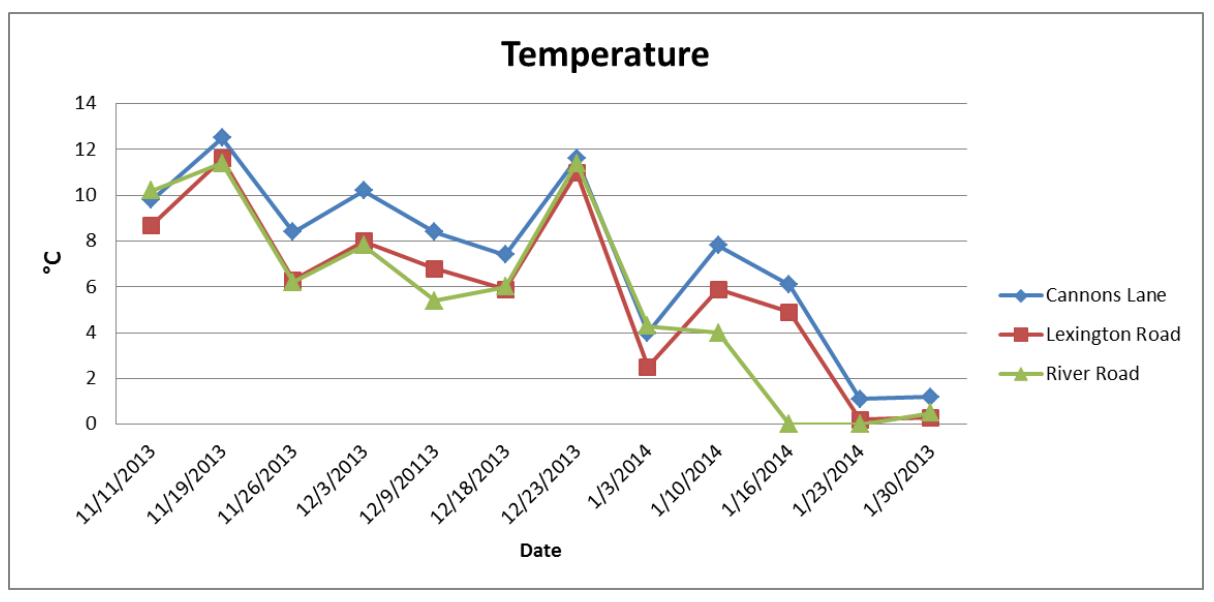

Figure 8 depicts the temperature levels between the three gauge sites.

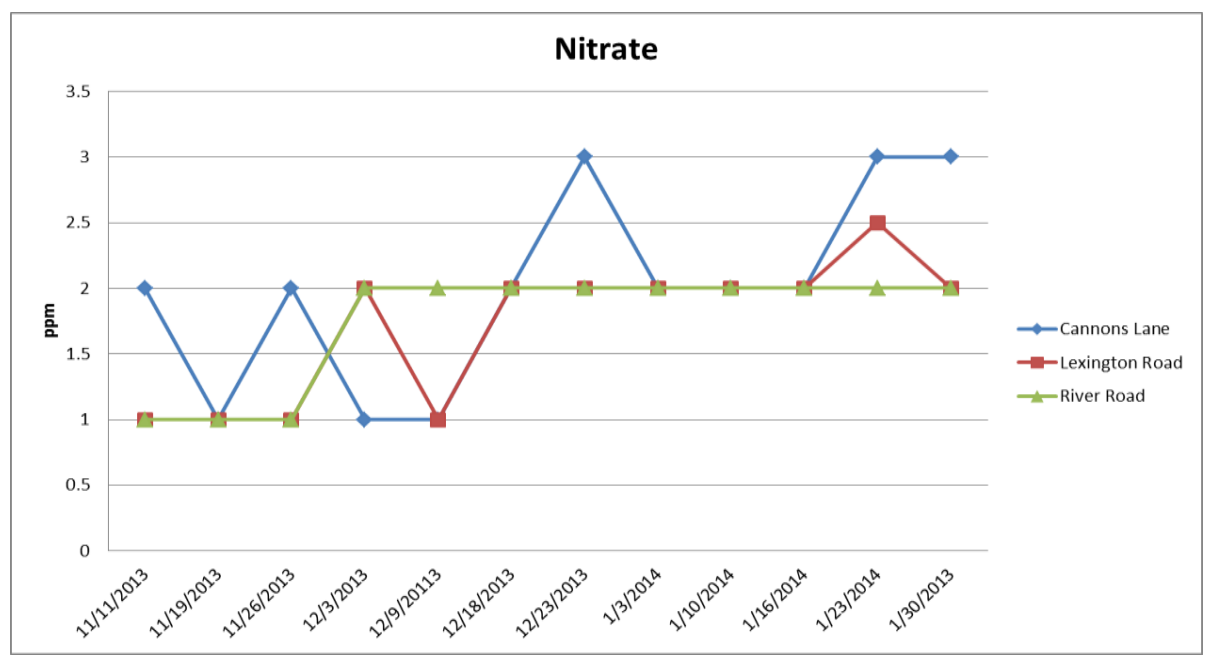

Figure 9 illustrates the nitrate levels between the three gauge sites.

27 


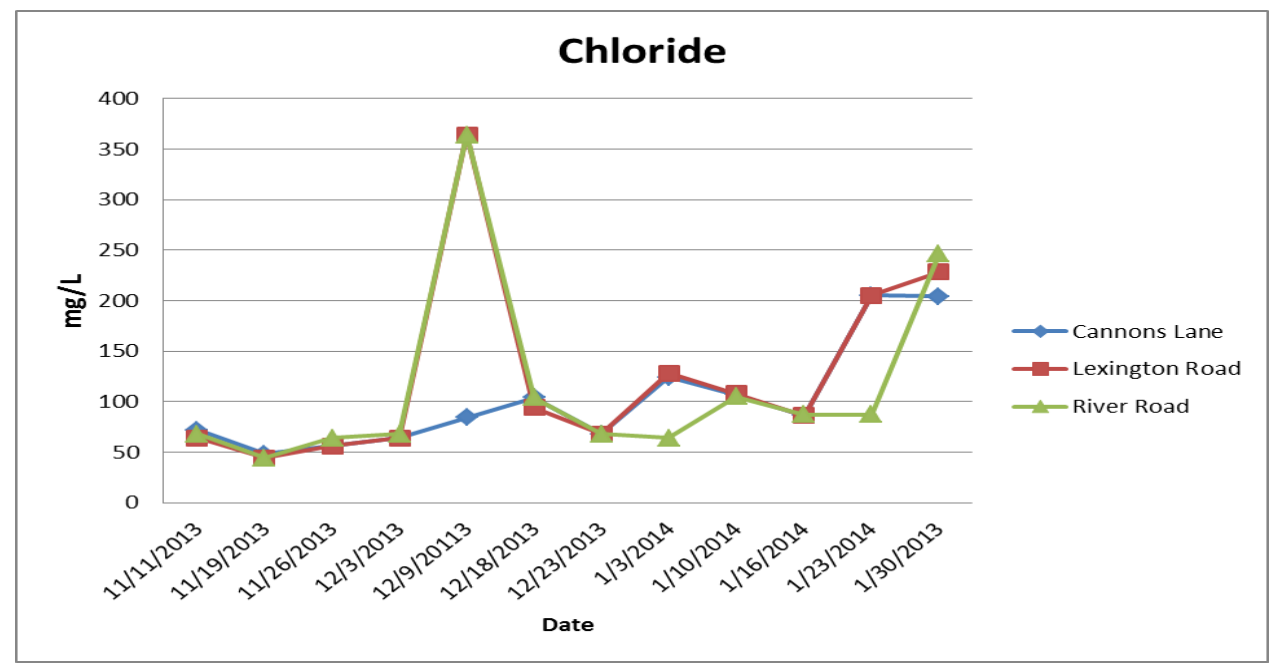

Figure 10 demonstrates the chloride levels between the three gauge sites.

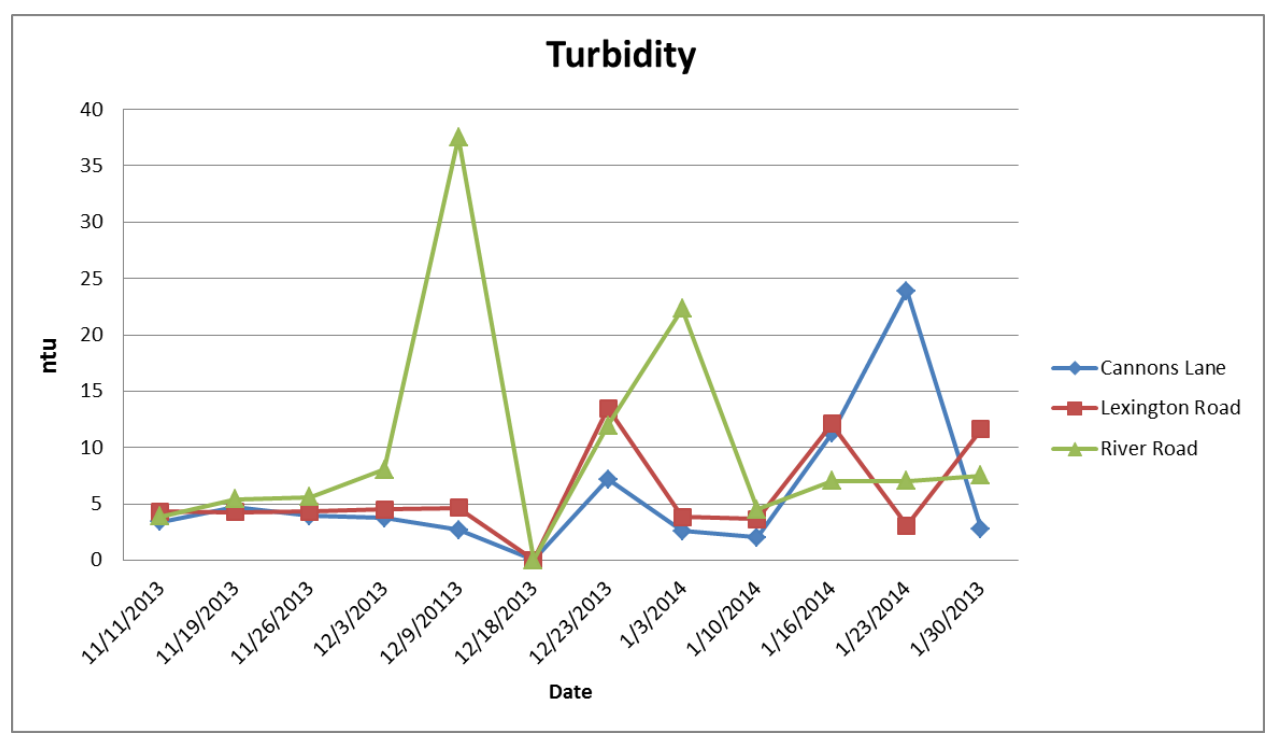

Figure 11 illustrates the turbidity levels between the three gauge sites.

\subsubsection{Dissolved Oxygen (DO)}

The lowest DO concentrations between November - January were at the two upstream gauges, measuring 0.3 to $2.8 \mathrm{mg} / \mathrm{L}$. These lowest DO ranges from Cannons Lane and Lexington Road are classified as outliers in the associated boxplots (Figure 12). The downstream site at River Road recorded a low of $6.1 \mathrm{mg} / \mathrm{L}$ with a maximum of 15.7 mg/L, being the highest between the three sites. According to the DOW standards (Table 
1) the threshold for $\mathrm{DO}$ is $4.0 \mathrm{mg} / \mathrm{L}$ or greater. However, the two upstream gauges showed only two instances where the DO was less than $4.0 \mathrm{mg} / \mathrm{L}$. This could be due to the increase in temperature and decrease in stream flow within the creek at these times. The DO concentrations were relatively high due to the lower temperatures in the winter months, as expected.

The Pearson"s Coefficients, seen under section 5.1.3, were used to help determine the correlation relationship between the water quality variables (Table 5). DO and temperature showed a negative correlation upstream at -0.686 , midstream -0.845 , and downstream -0.937 , further demonstrating that as temperature decreased the levels of DO increased leading to an inverse correlation between the two variables. DO also indicated positive correlation with $\mathrm{SC}$ at the upstream gauges ( 0.781 and 0.584$)$. This could be due to the temperature decrease during the winter months.

The average DO concentrations from upstream to downstream were calculated as $11.15,10.60$, and $10.16 \mathrm{mg} / \mathrm{L}$. The water quality would therefore not be classified as impaired based on the DO measurements taken along the Middle Fork (DOW).

\subsubsection{Specific Conductivity (SC)}

$\mathrm{SC}$ varied greatly over each sampling site ranging from $0.6-1,580 \mu \mathrm{S} / \mathrm{cm}$. The minimum SC at the upstream, midstream, and downstream sites was $0.6,563$, and 580 $\mu \mathrm{S} / \mathrm{cm}$. The maximum values at the three sites was 1310,1310 , and $1580 \mu \mathrm{S} / \mathrm{cm}$. The average SC at the upstream, midstream, and downstream gauges was 773,842 , and 874 $\mu \mathrm{S} / \mathrm{cm}$. Figure 12 indicates Cannons Lane and River Road to have both low and high outliers. Cannons Lane indicates one lower outlier from its median value (0.6). River 
Road shows one lower outlier (580) but two outliers that were higher (1300 and 1580) than the median value.

Seasonal conditions are correlated to the rise and fall of SC. In particular the discharge plays an important role in the rise or fall of the SC. If the discharge levels increase so do the levels of SC as there is greater potential for streambed and bank erosion to generate additional solid matter. Temperature also shows significant correlations with SC. Cannons Lane and Lexington Road indicated a negative significant correlation with temperature at $-0.652,-0.704$. This was initially unexpected as SC will normally increase under warmer conditions which allow for a greater dissolution of salts and minerals. However, this negative correlation with temperature may be due to the addition of excess road salts in the area in response to the colder air temperatures.

To back this up, chloride shows a positive correlation with SC at each sampling site. The upstream gauge has a significant correlation of 0.606 , midstream 0.948 , and downstream 0.948 displaying that as the levels of chloride increase the levels of SC would also increase at each gauge. Again, the increases in the SC could be due to the melting of snow within the basin depositing road salts and other chemical constituents into the stream system. The DOW does not provide any standards for SC within Kentucky.

\section{$5.2 .3 \mathrm{pH}$}

The $\mathrm{pH}$ between all three sites stayed within the range of 7-9. The lowest $\mathrm{pH}$ measured upstream was 7.6 (classified as an outlier in the boxplots Figure 12), midstream 7.6, and downstream 7.1. The maximum $\mathrm{pH}$ measured 8.6, 8.2, and 7.8 at the upstream, 
midstream, and downstream gauges. The averages of $\mathrm{pH}$ between each station were 8.2, 7.9, and 7.6.

$\mathrm{pH}$ can increase especially during the winter months due to the colder water temperatures. Higher $\mathrm{pH}$ values (above 7) may also be a result of runoff from impervious concrete surfaces containing weathered calcium and from fertilizers from golf courses, and residential/agricultural sources. Figure 7 illustrates an increase in $\mathrm{pH}$ at Cannons Lane then a slight decrease downstream, for example. This could be due to the golf course and airport adjacent to the Cannons Lane site. According to the DOW standards the $\mathrm{pH}$ levels indicate that the Middle Fork is not impaired since all values range between 7-9, within the minimum standards.

\subsubsection{Temperature}

Within the 12 week sampling timeframe (November 2013 - January 2014) the water temperature ranged between $0.2-12^{\circ} \mathrm{C}$. The average temperature between the three sites was $7.4,6,6.7^{\circ} \mathrm{C}$ respectively. The temperature stayed relatively consistent between each station over time (Figure 8). The median temperature decreases slightly from Cannons Lane to Lexington Road (Figure 12). The minimum allowable average water temperature, according to the DOW, is between $7-19^{\circ} \mathrm{C}$ during the months of November - January (Table 2). The instantaneous temperature does not exceed the DOW minimum standards of $31.7^{\circ} \mathrm{C}$ at any time. Temperature indicates significant negative correlation with DO $(-0.686,-0.845,-0.937)$ at all three stations, again as expected. The instantaneous temperature results do not indicate any impairment based on the DOW standards. 


\subsubsection{Nitrate}

Nitrate did not indicate any obvious change between the three sites. The ranges demonstrated $1-3 \mathrm{ppm}$ at the upstream, midstream, and downstream sites. However, the highest values (3ppm) were seen at Cannons Lane. As mentioned before, section 5.2.3, Cannons Lane is adjacent to a golf course where pesticides and/or fertilizers could be sourced from along with surrounding low density urban (59.6\% landcover) and urban (18\% landcover) areas. Nitrate also indicates a significant correlation with chloride (0.655) at Cannons Lane, which again could be from the runoff of road salt or potential sewage overflows within the area (Figure 3). However, the Middle Forkes water quality would not be classified as impaired based on the Nitrate measurements over the 12 weeks, as values never exceeded the maximum allowable level of $10 \mathrm{ppm}$ established by the DOW standards.

\subsubsection{Chloride}

The lowest chloride values were upstream at $48 \mathrm{mg} / \mathrm{L}$, midstream $44 \mathrm{mg} / \mathrm{L}$, and downstream $44 \mathrm{mg} / \mathrm{L}$. The maximum chloride levels present in the water upstream, midstream, and downstream were 205, 364, and $364 \mathrm{mg} / \mathrm{L}$. Figure 12 shows each site having at least one outlier. Cannons Lane has two outliers that overlap (204 and 205 $\mathrm{mg} / \mathrm{L}$ ) with one another. Lexington Road indicates one outlier of $364 \mathrm{mg} / \mathrm{L}$ that is outside of the median. River Road has two outliers outside of the median of 264 and $364 \mathrm{mg} / \mathrm{L}$. These higher values of chloride could be due to the additional runoff from impervious surfaces. As seen in Section 5.2.5 runoff from road salts may cause an increase in chloride levels. The average chloride levels recorded at each gauge were calculated to be 102,126 , and $114 \mathrm{mg} / \mathrm{L}$ at the upstream, midstream, and downstream sites respectively. 
The water quality would therefore not be classified as impaired as no values exceeded the maximum allowable value of $1200 \mathrm{mg} / \mathrm{L}$ set by the DOW standards.

\subsubsection{Turbidity}

Figure 12 indicates the upstream and downstream gauges to have high outliers. The turbidity ranges from 11.25 to 23.90 ntu at Cannons Lane and 22.3 to $37.5 \mathrm{ntu}$ at River Road. The highest turbidity value was found at the River Road site farthest downstream (37.5 ntu) while also illustrating a significant correlation with chloride (0.691).The correlation with chloride may again be a result of snowmelt from the winter months depositing much of the road salts, from impervious surfaces downstream. An increase in turbidity levels can also be due to the increase of discharge downstream (Figure 4). Major factors that would increase the levels of turbidity downstream would include a greater number of sewage outlets (approximately 328) and the fact that the downstream gauge collects discharge from a greater area, including forested and grassland areas. 

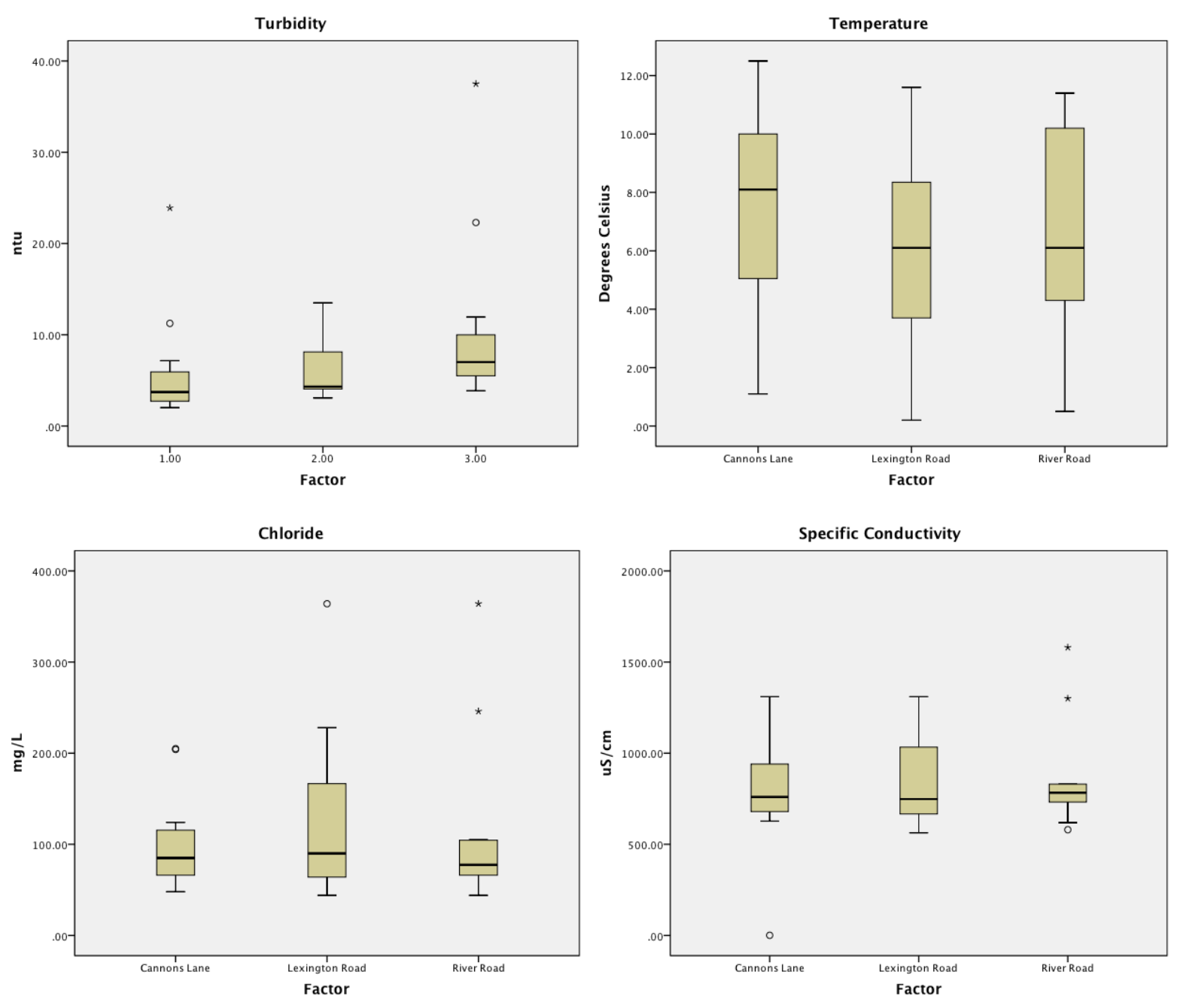

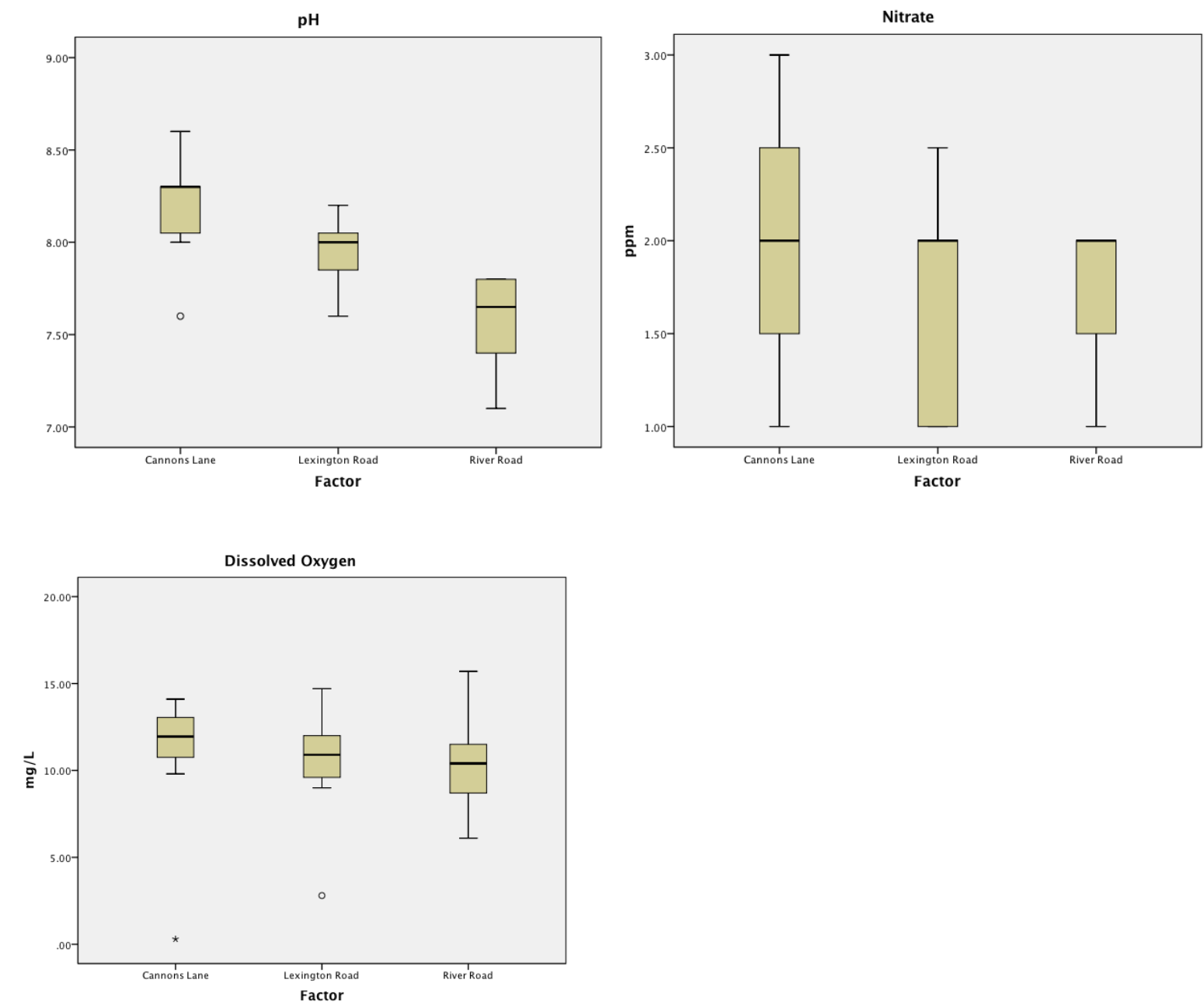

Figure 12 Boxplots illustrating each water quality variable between the three different stream gauges. 


\subsection{Kolmogorov-Smirnov Test}

The Kolmogorov-Smirnov Test was applied to check for the presence of a normal distribution for each water quality variable to determine whether ANOVA or KruskalWallis statistical tests would need to be applied for further analysis. The samples were analyzed based on a 95\% confidence level (P-value $<0.05)$. Each variable showed a pvalue less than 0.05 indicating the lack of a normal distribution with the exception of $\mathrm{pH}$ and temperature (Table 6). These two variables illustrated normality $(\mathrm{pH}, \mathrm{p}=0.200$; temperature, $\mathrm{p}=0.200)$.

\section{Table 6}

$\underline{\text { Kolmogorov-Smirnov test }}$

\begin{tabular}{ll}
\hline Sample & Significance \\
\hline & 0.000 \\
$* *$ Turbidity & 0.000 \\
$* *$ Nitrate & 0.000 \\
$* *$ Chloride & 0.200 \\
$*$ Temperature & 0.036 \\
$* * \mathrm{DO}$ & 0.200 \\
$* \mathrm{pH}$ & 0.000 \\
$* * \mathrm{SC}$ & \\
\hline$* * \mathrm{p}<0.05$ no normality (K-W test applies) \\
$* \mathrm{p}>0.05$ normality (ANOVA test applies)
\end{tabular}




\subsubsection{ANOVA}

ANOVA was used to check for significant differences in the mean values of $\mathrm{pH}$ and temperature between the three sites. The ANOVA was based on a $95 \%$ confidence level (P-value $<0.05$ ). The null hypothesis of no significant difference between the variable means between each site would then be rejected if the P-value were equal to or less than 0.05 .

The results showed that mean $\mathrm{pH}$ values did significantly differ between the three sites $(p=0.000)$, while temperature did not $(p=0.658)$. The highest $\mathrm{pH}$ values were measured at $8.6,8.2$, and 7.8 at the upstream, midstream, and downstream gauges accordingly. The upstream gauge has the highest $\mathrm{pH}$ value likely due to the adjacent golf course and higher proportion of urban and low density urban landcover combined where runoff from weathered calcium or fertilizers could increase the levels of $\mathrm{pH}$.

\subsubsection{Kruskal-Wallis Test}

The Kruskal-Wallis test was then applied to the water quality variables that did not display normality based on the Kolmogorov-Smirnov test $(\mathrm{p}<0.05)$. These variables included DO, chloride, nitrate, $\mathrm{SC}$, and turbidity. This test was to determine if there were any significant differences in the median values of each variable between the three sites. The null hypothesis of no significant differences was rejected at $\mathrm{p}<0.05$.

The Kruskal-Wallis test illustrated turbidity $(\mathrm{p}=0.038)$ as the only variable to show significant differences between the median of variables (Table 7). Thus the MannWhitney test was only applied to turbidity between each site to determine the exact location of significant median differences. 


\section{Table 7}

$\underline{\text { Kruskal - Wallis Test }}$

\begin{tabular}{ll}
\hline \multicolumn{1}{c}{ Sample } & Significance \\
\hline *Turbidity & 0.038 \\
Nitrate & 0.541 \\
Chloride & 0.948 \\
DO & 0.186 \\
SC & 0.892 \\
\hline \hline
\end{tabular}

$* p<0.05$ indicates a significant difference in the median of the variables between the three sites.

\subsubsection{Mann-Whitney Test}

The Mann-Whitney test (non-parametric t-test) was applied to determine where the significant difference in median turbidity occurred between the upstream, midstream, and downstream sites. The results indicated that turbidity showed a significant difference between the upstream and downstream sites $(\mathrm{p}=0.028)$ with higher levels recorded downstream (Table 8). Higher turbidity values at this downstream site are expected due to the accumulation of solids washed down from all three watersheds that make up Beargrass Creek. In particular, this site has the largest proportion of forested and grassland cover upstream which would significantly increase the source area for solid material, especially during the winter months when there is less vegetation cover. 


\section{Table 8}

Mann - Whitney Test

\begin{tabular}{lll}
\hline Sample & Site & Significance \\
\hline \multirow{2}{*}{ Turbidity } & Cannons/Lexington & 0.217 \\
& Cannons/River & 0.028 \\
& Lexington/River & 0.065 \\
& \\
\hline${ }^{p} \mathrm{p}<0.05$ indicates a significant difference &
\end{tabular}




\subsection{CONCLUSIONS}

The purpose of this study was to determine whether water quality diminished as a result of increasing pollution downstream along the Middle Fork of Beargrass Creek, Kentucky. Data was collected along the Middle Fork of Beargrass Creek for 12 weeks (November - January). The data collected helped determine the characteristics of water quality along three stream segments of a typical urbanized stream system.

The water quality variables at each site indicated several significant statistical correlations. Cannons Lane indicated 3 positive correlations (nitrate and chloride, DO and SC, and SC and chloride), along with 3 negative correlations (chloride and temperature, temperature and $\mathrm{DO}$, and temperature and SC) between water quality variables. Lexington road showed 3 positive ( $\mathrm{SC}$ and chloride, DO and $\mathrm{SC}$, and $\mathrm{pH}$ and DO) and 3 negative (DO and temperature, $\mathrm{pH}$ and temperature, and $\mathrm{SC}$ and temperature) correlations. River Road showed 3 positive (chloride and turbidity, SC and chloride, and $\mathrm{DO}$ and $\mathrm{pH}$ ) and 2 negative correlations (temperature and $\mathrm{pH}$, and $\mathrm{DO}$ and temperature) between each water quality variable.

To check if water quality did diminish downstream as a function of urbanization, firstly, the Kolmogorov-Smirnov Test $(\mathrm{P}$-value $<0.05$ ) was applied to each water quality variable. Temperature and $\mathrm{pH}$ were the only two variables to indicate a normal distribution. 
Secondly, ANOVA was used to determine the significant differences in the mean values of $\mathrm{pH}$ and temperature between the three sites. The $\mathrm{pH}$ values indicated a significant difference between each site, with higher values upstream, likely due to the adjacent landcover.

Thirdly, the Kruskal-Wallis test demonstrated that only turbidity showed significant differences between the median values at each site. Thus, the Mann-Whitney test was applied to determine the location of significant difference in median turbidity levels between each site. The results concluded that there were significant differences of turbidity upstream and downstream, with higher values found downstream.

Overall, the water quality did not diminish downstream along the Middle Fork of Beargrass Creek within the sampling period as hypothesized. The only variables to show statistically significant differences between each sampling gauge were $\mathrm{pH}$ and turbidity. This could be due to the fact that urban and low density urban landcover actually decreased in proportion downstream. Typically, these land covers will generate greater instances of pollution to diminish water quality in general. Furthermore, forest, grassland, and wetland areas increased downstream. These land covers will often act as sinks to potential chemical and biological water pollutants, trapping or delaying their entry into stream systems. However, these landcovers may also increase the presence of physical pollutants like solid particulate matter, to increase turbidity accordingly.

Another factor potentially impacting the results of this study could be the timing and frequency of the water quality sampling. Samples were only collected once a week depending on equipment availability. More frequent sampling that also incorporated significant rainfall events would have been preferred as these events have the potential to 
impact discharge as well as flush out untreated sewage from the many outlets located adjacent to the Middle Fork. As a result this could have been a significant factor in determining the overall water quality between the three sites as this study established a baseline for normal flow conditions.

Further analysis could also incorporate water quality samples being collected across different seasons, rather than being limited to late Fall/early Winter. Summer sampling, for example would likely include lower DO values in response to the warmer temperatures, along with the possible associated impacts on other water quality variables. A more rigorous sampling schedule would also open up opportunities to monitor other key water quality and pollution variables, including phosphorus, coliform bacteria, and chemical oxygen demand. This would ultimately allow a more thorough analysis into potential links between land cover and water quality within the Middle Fork of Beargrass Creek. 


\section{REFERENCES}

Bayram, A., H. Onsoy, V. N. Bulut, and G. Aknci. 2013. Influences of urban wastewaters on the stream water quality: a case study from Gumushane Province, Turkey. Environmental Monitoring Assessment 185: 1285-1303.

Barco J., S. Papiri, and M. K. Stenstrom. 2008. First flush on a combined sewer system. Chemoshpere 71: 827-833.

Brilly, M., S. Rusjan, and A.Vidmar. 2006. Monitoring the impact of urbanization on the Glinscica stream. Physics and Chemistry of the Earth 31: 1089-1096.

Connors, B. 2004. Protocols for collecting water grab samples in rivers, streams, and freshwater wetlands. Division of Environmental Assessment Biological Monitoring Program. Portland, ME: Department of Environmental Protection.

Cordy, G. E. 2013. USGS science for a changing world. A primer on water quality. Available at http://pubs.usgs.gov/fs/fs027-01/ (last accessed 9 January 2013).

Edelmann, P., S. A. Ferguson, R. W. Stogner Sr., M. August, W. F. Payne, and J. F. Bruce. 2005. Evaluation of water quality, suspended sediment, and stream morphology with an emphasis on effects of stormflow on Fountain and Monument Creek Basins, Colorado Springs and vicinity, Colorado, 1981-2001. Water Resources Investigations Report 02-4104. Denver, CO: USGS.

Gerner S. J., and K. M. Waddell. 2003. Hydrology and water quality of an urban stream reach in the great basin - Little Cottonwood Creek near Salt Lake City, Utah, water years 1999-2000. USGS Water-Resources Investigations Report 02-4276. Salt Lake City, Utah: USGS.

Gray, L. 2004. Change in water quality and macroinvertebrate communities resulting from urban stormflows in the Provo River, Utah, USA. Hydrobiologia 518: 3346.

Gray, J., P. Fitzgerald, and M. Trumbo. 2011. State of the streams. Water Quality Synthesis Report. Louisville, KY: Louisville and Jefferson County Metropolitan Sewer District (MSD). 
Haidary, A., B. J. Amiri, J. Adamowski, N. Fohrer, and K. Nakane. 2013. Assessing the impacts of four land use types on the water quality of wetlands in Japan. Water Resource Management 27: 2217-2229.

Helms, B. S., J. E. Schoonover, and J. W. Feminella. 2009. Assessing influences of hydrology, physiochemistry, and habitat on stream fish assemblages across a changing landscape. Journal of the American Water Resources Association 45:157-169.

Jarrett, G.L., A.C. Downs, and P. A. Grace-Jarrett. 1998. Continuous hydrologic simulation of runoff for the Middle Fork and South Fork of the Beargrass basin in Jefferson County, Kentucky. USGS Water-Resources Investigations Report 98- 4182. Louisville, KY: USGS.

Jin, S., L. Yang, P. Danielson, C. Homer, J. Fry, and G. Xian. 2013. A comprehensive change detection method for updating the National Land Cover Database to circa 2011. Remote Sensing of Environment 132: 159-175.

Kentucky Division of Water. 2014. Title 401 energy and environment cabinet department for environmental protection. Chapter 10 water quality standards; section 4 aquatic life. Available at http://lrc.ky.gov/kar/401/010/031.htm (last accessed 24 February 2014).

Louisville/Jefferson County Information Consortium (LOJIC). 2013. Database index. http://www.lojic.org/main/metadata/index.html\#Jefferson (last accessed 3 July 2014).

Marsh, G. P. 1965. Man and nature. Seattle, WA: University of Washington Press.

Metropolitan Sewer District (MSD) 1999. Waters of Jefferson County-year zero: Middle Fork Watershed. Louisville, KY: Louisville and Jefferson County MSD.

Metropolitan Sewer District (MSD) 2005. Beargrass Creek Watershed: State of the Streams. Louisville, KY: Louisville and Jefferson MSD.

National Institute of Environmental Health Sciences. 2014. Water pollution. Available at http://www.niehs.nih.gov/health/topics/exposure/water-poll/index.cfm (last accessed 13 May 2014)

National Land Cover Dataset (NLCD). 2013. National landcover database 2011. Product legend. Available at http://www.mrlc.gov/nlcd11 leg.php (last accessed 3 July 2014).

Perlman, H. 2013. USGS water science school. Available at http://water.usgs.gov/edu/ (last accessed 14 August 2013). 
Peters, N. E. 2009. Effects of urbanization on stream water quality in the city of Atlanta, Georgia, USA. Hydrological Processes 23: 2860-2878.

Peters, N. E., and M. Meybeck. 2000. Water quality degradation effects on freshwater availability: Impacts of human activities. Water International 25 (2): 185-193.

Riseng, C. M., M. J. Wiley, and R. J. Stevenson. 2004. Hydrologic disturbance and nutrient effects on benthic community structure in Midwestern US streams: A covariance structure analysis. Journal of the North American Benthological Society 23(2): 309-326.

Ruhl, K. J., and G. L. Jarrett. 1999. Processes affecting dissolved-oxygen concentrations in the lower reaches of Middle Fork and South Fork Beargrass Creek, Jefferson County, Kentucky. USGS Water-Resources Investigations Report 98-4218. Louisville, KY: USGS.

Sartor, J. D., G. B. Boyd, and F. J. Agardy. 1974. Water pollution aspects of street surface contaminants. WPCF 46 (3): 458-466.

Tu, J. 2013. Spatial variations in the relationships between land use and water quality across an urbanization gradient in the watersheds of northern Georgia, USA. Environmental Management 51:1-17.

Tufail, M, and L. Ormsbee. 2009. Optimal water quality management strategies for urban watersheds using macrolevel simulation and optimization models. Journal of Water Resources Planning and Management 135 (4): 276-285.

U.S. Environmental Protection Agency (EPA). 2012. Nitrates. Available at http://water.epa.gov/type/rsl/monitoring/vms57.cfm (last accessed 6 March 2012).

U.S. Environmental Protection Agency (EPA). 2013. Impaired waters and total maximum daily loads. Available at http://water.epa.gov/lawsregs/lawsguidance/cwa/tmdl// (last accessed 3 July 2014).

U.S. Geological Survey (USGS). 2013. USGS water data for the nation. http://waterdata.usgs.gov/nwis (last accessed 3 July 2014).

Wenner, D. B., M. Ruhlman, and S. Eggert. 2003. The importance of specific conductivity for assessing environmentally impacted streams. Proceedings of the 2003 Georgia Water Resources Conference 15: 1-3. 


\section{CURRICULUM VITA}

NAME: Olivia Catherine Lee Heringer Brooks

ADDRESS: 5515 Hames Trace Apt. 520

Louisville, KY 40291

DOB: $\quad$ Cincinnati, Ohio - February 9, 1990

\section{EDUCATION}

\& TRAINING: $\quad$ B.S., Environmental Studies

Northern Kentucky University

2008-2012

M.S., Applied Geography

University of Louisville

2012-2014 